\title{
Application of Hot Start PCR Method in PCR-based Preimplantation Genetic Diagnosis
}

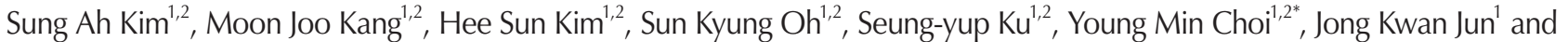 \\ Shin Yong Moon ${ }^{1,2}$ \\ ${ }^{1}$ Department of Obstetrics and Gynecology, Seoul National University Hospital, Seoul, Korea \\ ${ }^{2}$ The Institute of Reproductive Medicine and Population, Medical Research Center, Seoul National University College of Medicine, Seoul, Korea
}

\begin{abstract}
Purpose: To determine a method to improve the efficacy and accuracy of preimplantation genetic diagnosis (PGD) polymerase chain reaction (PCR), we compared hot start PCR and conventional multiplex nested PCR.

Materials and Methods: This study was performed with single lymphocyte isolated from whole blood samples that were obtained from two couples with osteogenesis imperfecta (OI). We proceeded with conventional multiplex nested PCR and hot start PCR in which essential reaction components were physically removed, and we compared the amplification rate, allele dropout rate and nonspecific products. Afterward, we used selective method for PGD.

Results: In the two couples, the respective amplification rate were $93.5 \%$ and $80.0 \%$ using conventional multiplex nested PCR and $95.5 \%$ and $92.0 \%$ using hot start PCR. The respective mean allele dropout rates for the two couples were $42.0 \%$ and $14.0 \%$ with conventional multiplex nested PCR and $36.0 \%$ and $6.0 \%$ with hot start PCR.

Conclusion: The results demonstrate that the hot start PCR procedure provides higher amplification rates and lower allele dropout rate than the conventional method and that it decreased the nonspecific band in multiplex nested PCR. The hot start method is more efficient for analyzing a single blastomere in clinical PGD.
\end{abstract}

Key Words: Hot start PCR, Nested PCR, Preimplantation genetic diagnosis

\section{Introduction}

Preimplantation genetic diagnosis (PGD) is a genetic analysis that uses a single blastomere before the embryo transfer step of in vitro fertilization (IVF). Advances in molecular biology and IVF have enabled the use of PGD. Previous reports on the use of PGDPCR related to the Y-specific DNA amplification on the first PGDPCR cycle, originated in England in 1990.") Recently advanced assay techniques have provided the opportunity to improve the diagnosis of single gene disorders. In particular, PCR has become a highly efficient technique that can rapidly diagnose a variety of single gene defects. ${ }^{2,3)}$ However, PCR using a single cell cause errors in diagnosis, such as allele dropout because of a low concentration of DNA.

The Taq polymerase included with PCR regents has especially high activity at $37^{\circ} \mathrm{C} .^{5)}$ In front case, the researchers may obtain a result in which they fail to amplify the correct band or get to obtain nonspecific bands because of a high mismatch with primers. Thus, fine-tuning PCR conditions can be an intensive process that is susceptible to all the problems of conventional PCR. ${ }^{3)}$

The hot start PCR method has been reported to decrease the amount of nonspecific products and primer artifacts. ${ }^{6}$ In brief,

Received: 8 March 2012, Revised: 18 May 2012, Accepted: 22 May 2012, Published: 30 June 2012

${ }^{*}$ Corresponding author: Young Min Choi, M.D, Ph.D.

Department of Obstetrics and Gynecology, Seoul National University College of Medicine, 28 Yongon-Dong, Chongno-Gu, Seoul, 110-744, Korea

Tel: +82-2-2072-2385, Fax: +82-2-762-3599, E-mail: ymchoi@snu.ac.kr

(c) This is an open-access article distributed under the terms of the Creative Commons Attribution Non-Commercial License (http://creativecommons.org/licenses/by-nc/3.0/) which permits unrestricted non-commercial use, distribution, and reproduction in any medium, provided the original work is properly cited.

(c) Copyright 2012 by the Korean Society of Medical Genetics

www.e-kjgm.org 
activation of the polymerase occurs after the complete denaturation of DNA. PG PG is generally performed with multiplex nested PCR that detects several polymorphisms in a single blastomere, and hot start PCR may therefore have some advantages. There have been a few reports on the hot start PCR method for PGD. ${ }^{8)}$ However, no reports have compared hot start PCR with conventional multiplex nested PCR infor PGD.

We conducted a study comparing hot start PCR, in which essential reaction components were removed, with conventional multiplex nested PCR. We presumed that manual hot start PCR would provide optimal PGD-PCR conditions with a single blastomere on account of the effectiveamplification of the targetgene, which requiresa PGD.

\section{Materials and Methods}

\section{Study samples}

For this study, we used whole blood samples donated by two couples with osteogenesis imperfecta (OI) who visited Seoul National University Hospital. We isolated single lymphocytes from each blood sample using the method outlined below. One of the couples underwent a PGD at a later time.

In the first couple (family 1), both partners had a causal mutation. The female partner carried a mutation in the COL1A1 gene (c.3470 $\mathrm{G}>\mathrm{A}$ ), and the male partner carried a mutation as well (IVS15+5G $>A$ ). In the second couple (family 2), the female partner had the causal mutation. The mutation was in the COL1A2 gene (c.3803_3805dup). The mutations of these couples were diagnosed in the other institution (Labgenomics clinical laboratories, Sungnam, KR), where wereceived related materials.

\section{Isolation of single lymphocytes}

Whole blood samples were collected in heparinized tubes. Three milliliters of blood was layered onto Histopaque-1077 (Sigma, St. Louis, MO, USA) and centrifuged at $400 \mathrm{~g}$ for exactly $30 \mathrm{~min}$ at room temperature. The plasma layer was carefully discarded, and the mononuclear cell fraction was aspirated into a clean conical centrifuge tube. The layer was washed twice with Dulbecco's phosphate-buffered saline (PBS). The cell pellet was mixed in 1 $\mathrm{mL}$ of Roswell Park Memorial Institutes (RPMI) medium (Gibco, Rockville, MD, USA) containing 10\% dimethyl sulfoxide (Merck, Rahway, NJ, USA) and was then frozen at $-20^{\circ} \mathrm{C}$ until use. For the isolation of single lymphocytes, an aliquot of the cell suspension was thawed and $20 \mu \mathrm{L}$ was added to $4 \mathrm{~mL}$ RPMI medium, supple- mented with 10\% serum substitute supplement (Irvine Scientific, Santa Ana, CA) in a culture plate. Single lymphocytes were aspirated using a pasteur pipette under an inverted microscope and transferred to $0.2 \mathrm{~mL}$ PCR tubes containing $3 \mu \mathrm{L}$ alkaline lysis buffer (ALB) which were then centrifuged, and heated at $65^{\circ} \mathrm{C}$ for $10 \mathrm{~min}$.

\section{Conventional multiplex nested PCR}

The methods of conventional multiplex nested PCR were modified from Girardet et al. ${ }^{9)}$ Some of the primers have been previously described in Lab genomics clinical laboratories, while others had to be specially designed based sequences of Primer 3 (V.0.4.0, http:// frodo.wi.mit.edu/). Additional multiplexing was performed with the ZFX/ZFY gene forsexing. The first round of PCR was performed in a $30 \mu \mathrm{L}$ volume containing $3 \mu \mathrm{L}$ of neutralization buffer [900 mM Tris- $\mathrm{HCl}$ (pH 8.3), $300 \mathrm{mM} \mathrm{KCl}$ and $200 \mathrm{mM} \mathrm{HCl}, 3 \mu \mathrm{L}$ of $\mathrm{K}^{+}$-free buffer [30 mM MgCl2, 1.5M Tris- $\mathrm{HCl}$ and 1\% gelatine], $2.5 \mathrm{mM}$ dNTPs (Takara, Otsu, Shiga, Japan), $0.6 \mu \mathrm{L}$ of each outer primer (Table 1) and $1 \mathrm{IU}$ Taq DNA polymerase (Takara). The following program was used: 4 min at $96^{\circ} \mathrm{C} ; 25$ cycles of $30 \mathrm{~s}$ at $96^{\circ} \mathrm{C}, 30 \mathrm{~s}$ at $62^{\circ} \mathrm{C}$, and $1 \mathrm{~min}$ at $72^{\circ} \mathrm{C}$; and $10 \mathrm{~min}$ at $72^{\circ} \mathrm{C}$. One micro liter of the firstround PCR products was then reamplified in a second PCR. All $\mathrm{PCR}$ reactions contained $1 \mu \mathrm{L}$ of reaction buffer $[20 \mathrm{mM}$ Tris- $\mathrm{HCl}$ (pH 8.0), $100 \mathrm{mM} \mathrm{KCl}, 0.1$ mM EDTA, 1 mM DTT, 0.5\% Tween 20, 0.5\% Nonidet P-40 and 50\% glycerol], $2.5 \mathrm{mM}$ dNTPs, nested primers and 1 IU Taq DNA polymerase, in a total volume of 10 $\mu \mathrm{L}$. The following program was used: 4 min at $96^{\circ} \mathrm{C} ; 28$ cycles of $30 \mathrm{~s}$ at $96^{\circ} \mathrm{C}, 30$ s at $59^{\circ} \mathrm{C}$, and $1 \mathrm{~min}$ at $72^{\circ} \mathrm{C}$; and $10 \mathrm{~min}$ at $72^{\circ} \mathrm{C}$. All reactions were performed in MyCycler Thermal Cycler PCR machines (Bio-RAD, Hercules, CA, USA). Following the nested PCR, $10 \mu \mathrm{L}$ of the amplification products was electrophoresed on a $2 \%$ agarose gel (Cambrex, Rockland, ME, USA) containing ethidium bromide for $40 \mathrm{~min}$ at $120 \mathrm{~V}$ and then visualized by UV transillumination.

\section{Hot start PCR}

The methods of conventional multiplex nested PCR were modified from Malcov et al. ${ }^{8}$ The first round of PCR was performed in a $25 \mu \mathrm{L}$ volume containing $3 \mu \mathrm{L}$ of neutralization buffer [900 mM Tris- $\mathrm{HCl}$ (pH 8.3), $300 \mathrm{mM} \mathrm{KCl}$ and $200 \mathrm{mM} \mathrm{HCl}, 3 \mu \mathrm{L}$ of $\mathrm{K}^{+}$-free buffer [30 mM MgCl2, 1.5 M Tris-HCl and 1\% gelatine], 2 ul of 2.5 mM dNTP (Takara), $0.5 \mu \mathrm{L}$ of each outer primer (Table 1), $1 \mu \mathrm{L}$ of dimethyl sulfoxide (Merck) and distilled water. The mixture was preheated to $96^{\circ} \mathrm{C}$ for 8 min and was decreased temperature to $75^{\circ} \mathrm{C}$. At this time, $5 \mu \mathrm{L}$ of enzyme mixture was added. The enzyme 
Table 1. Primer sets used for preimplantation genetic diagnosis of osteogenesis imperfecta genes

\begin{tabular}{|c|c|c|c|c|}
\hline Primer & Mutation & Nucleotide sequence (5'-3') & Annealing Temperature $\left({ }^{\circ} \mathrm{C}\right)$ & Size (bp) \\
\hline ZFY Fext & $Z F X / Z F Y$ & ACC(AG)CTGTACTGACTGTGATTACAC & $63^{b} / 72^{c}$ & \\
\hline ZFY Rext & & GCAC(CT)TCTTTGGTATC(CT)GAGAAAGT & & \\
\hline ZFY Fint & & A(CT)AACCACCTGGAGAGCCACAAGCT & 59 & 344 bp \\
\hline ZFY Rint & & TGCAGACCTATATTC(AG)CAGTACTGGCA & & \\
\hline \multicolumn{5}{|l|}{ Family 1} \\
\hline US Fext & c. $3470 \mathrm{G}>\mathrm{A}$ & TGGTGGGCCTCTCCTCCAGAGCTGG & 63 & \\
\hline US Rext & & TATGGGCATGGGGACCCTGGCATGG & & \\
\hline US Fint & & AGCCTTTCTCAAACCATTTC & 59 & 227 bp \\
\hline US Rint & & CACAGAGAGGGAAGAGAGTG & & \\
\hline PT Fext & IVS15+5 G>A & CTCCCCAGGAACTCTAGGGACTGGC & 63 & \\
\hline PT Ra & & CCTGTGAATGAAATGGAGAT & & \\
\hline PT Fint & & GTGGAAATGATGGTGCTACT & 59 & 217 bp \\
\hline \multicolumn{5}{|l|}{ Family 2} \\
\hline JW Fext & c.3803_3805dup & TCAAАССТTTTCACСАAСTT & 72 & \\
\hline$J W R^{a}$ & & TGTAAGTGAACCTGCTGTTG & & \\
\hline JW Fint & & TGACCTTGCCTCAGTCTAGT & 59 & 389 bp \\
\hline
\end{tabular}

Primer Fext/Rext and Fext/R $R^{a}$ were used in the first round PCR, respectively. Primer Fint/Rint and Fint/R $R^{\text {a }}$ were used in the second round PCR, respectively. Annealing temperature of family $1^{b}$ and family $2^{c}$.

mixture consisted of 10 X PCR buffer, $25 \mathrm{mM} \mathrm{MgCl} 21.25 \mathrm{IU}$ Taq polymerase and distilled water. The following program was used: 2 min at $98^{\circ} \mathrm{C} ; 10$ cycles of $1 \mathrm{~min}$ at $96^{\circ} \mathrm{C}, 2$ min at $62^{\circ} \mathrm{C}$ and $3 \mathrm{~min}$ at $72^{\circ} \mathrm{C} ; 6$ cycles of 45 s at $94^{\circ} \mathrm{C}, 1 \mathrm{~min}$ at $62^{\circ} \mathrm{C}$ and 3 min at $72^{\circ} \mathrm{C}$; and $8 \mathrm{~min}$ at $72^{\circ} \mathrm{C}$. The second round of PCR was performed in a $10 \mu \mathrm{L}$ volume containing $1 \mu \mathrm{L}$ of reaction buffer $[20 \mathrm{mM}$ Tris- $\mathrm{HCl}$ (pH 8.0), 100 mM KCl, 0.1 mM EDTA, 1 mM DTT, 0.5\% Tween 20, $0.5 \%$ Nonidet P-40, $50 \%$ glycerol], $1 \mu \mathrm{L}$ of $2.5 \mathrm{mM}$ dNTPs, 0.75 $\mu \mathrm{L}$ of each inner primer, $1 \mu \mathrm{L}$ of dimethyl sulfoxide and distilled water. The following program was used: $8 \mathrm{~min}$ at $96^{\circ} \mathrm{C}$ and $30 \mathrm{~s}$ at $75^{\circ} \mathrm{C}$ (for addition of the enzyme mixture); 14 cycles of $2 \mathrm{~min}$ at $98^{\circ} \mathrm{C}, 1$ min at $96^{\circ} \mathrm{C}, 2$ min at $60^{\circ} \mathrm{C}$ and 2 min at $72^{\circ} \mathrm{C} ; 20$ cycles of 45 sat $94^{\circ} \mathrm{C}, 1$ min at $60^{\circ} \mathrm{C}$ and 2 min at $72^{\circ} \mathrm{C}$; and 10 min at $72^{\circ} \mathrm{C}$. The second enzyme mixture consisted of 10 X PCR buffer, 25 $\mathrm{mM} \mathrm{MgCl}$, 2 IU Taq polymerase and distilled water. All reactions were performed in MyCycler Thermal Cycler PCR machines (BioRAD). Following the nested PCR, $10 \mu \mathrm{L}$ of amplification products was electrophoresed on a 2\% agarose gel (Cambrex) containing ethidium bromide for $40 \mathrm{~min}$ at $120 \mathrm{~V}$ and then visualized by UV transillumination.

\section{Restriction fragment length polymorphism (RFLP) analysis}

RFLP analysis was performed by mixing $10 \mu \mathrm{L}$ of the ZFX/ZFY second-round PCR products with10 IU of the restriction enzyme Haelll (NEB, Ipswich, MA, USA) and $2 \mu \mathrm{L}$ of the supplied buffer in a total volume of $20 \mu \mathrm{L}$. The reaction tubes were incubated $37^{\circ} \mathrm{C}$ for $4 \mathrm{~h}$. The products of the enzymatic restriction digest were resolved by electrophoresis on a 4\% Nusieve agarose gel (Cambrex) containing ethidium bromide for $50 \mathrm{~min}$ at $120 \mathrm{~V}$ and then visualized by UV transillumination.

\section{Embryo biopsy}

The embryo biopsy was performed on the third day at the six to eight-cells stage. The biopsy and dissection of the zona pellucida were performed using a micromanipulator (Narshige, Tokyo, Japan) mounted on an inverted microscope (Nikon, Tokyo, Japan). The presence of a clearly visible nucleus guided the selection of the blastomere to be biopsied in G-PGD medium (Virolife, Goteborg, Sweden). Also, we decided on a number of biopsied blastomeres according to the cell stage. Biopsied one (embryo $\leq 6$ blastomere) or two blastomeres (embryos $\geq 8$ blastomere) were loaded in 3 $\mu \mathrm{L}$ of ALB buffer, and the genetic analysis was performed on the same day. Additionally, we tested removing some of the final wash drop as a negative control.

\section{Ethics}

The present study was approved by the Institutional Review Boards ofSeoul National University Hospital (\# 0909-056-296). 


\section{Statistical analysis}

The amplification rate and the rate of allele dropout (AD0) were compared using t-test. A value of $P<0.05$ was considered statisticallysignificant.

\section{Results}

\section{Amplification rate}

The PCR conditions were set up separately for each locus, and amplification success was judged by the presence of a single specific and correctly sized band of reasonable intensity for secondary PCR products analyzed on agarose gels. We obtained products of the secondary PCR corresponding to the mutation in each case.

The amplification rates for hot start PCR and conventional multiplex nested PCR were evaluated using single lymphocytes isolated from two couples. At least 50 cells from each mutation were analyzed for each method. The amplification efficiency for the first couple (family 1) ranged from 94.0\% to 96.0\% with hot start PCR and from $86.0 \%$ to $98.0 \%$ with conventional multiplex nested PCR (Table 2). The total amplification rate for hot start PCR was higher than for the conventional method but was not significantly higher. The results for the second couple (family 2) ranged from $89.0 \%$ to $95.0 \%$ with the hot start PCR method and from 69.0\% to $91.0 \%$ with the multiplex nested PCR method. The results for family 2 were statistically significant $(P<0.001)$.

Figure 1 shows the PCR bands obtained for each procedure of c.3470 G>A in COL1A1 from family 1. We were confirmed from these results that hotstart PCR lessened nonspecific products.

\section{ADO rate}

Ol is an autosomal dominant disorder, but additional multiplexing was performed with the ZFX/ZFY gene for sexing, for which we calculated the $A D O$ rate. The rate of $A D O$ was determined by Haelll digestion of the ZFX/ZFY nested PCR products. Secondround PCR products from XX cells (344 bp) were cut into two fragments of $300 \mathrm{bp}$ and $44 \mathrm{bp}$, and $X Y$ cells had four fragments of 300, 216, 84 and $44 \mathrm{bp}$. Analyzing single lymphocytes from the male individuals that gave positive amplification signals provided information on the degree of ADO at ZFX/ZFY. The data shown in Table 2 reveal that in family 1 , the rates of $A D O, 42.0 \%$ and $36.0 \%$, were not statistically different. However, in family 2, a statistically lower rate of $A D O$ was obtained with the hot start PCR procedure $(6.0 \%)$ than with the other method.

\section{Clinical case of PGD}

Following establishment of the hot start PCR protocol, PGD was performed in the clinic for family 2 . The couple visited the IVF clinic for PGD in order to have an unaffected baby. The husband was normal; the wife was diagnosed with OI due to a duplication of c.3803_3805 in COL1A2. They underwent a single IVF-PGD treatment cycle, although the female partner had a poor reaction of the ovarian stimulation. The results from this case are sum-

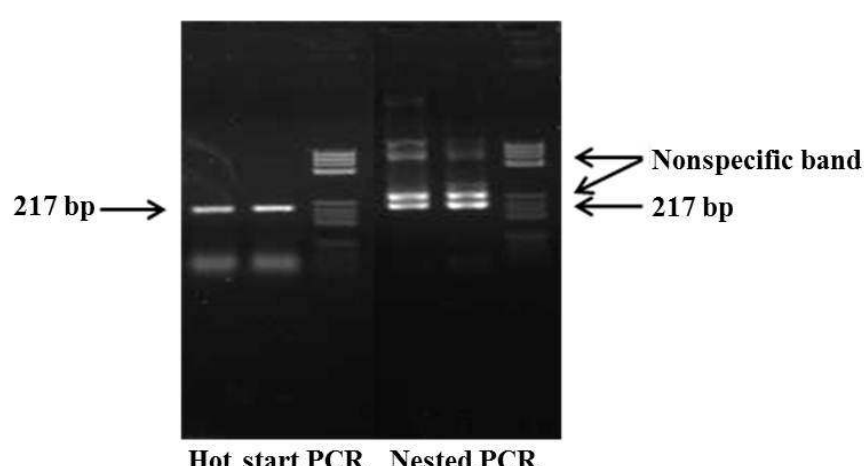

Fig. 1. Results of single lymphocyte genetic analysis using hot start PCR (left) and conventional multiplex nested PCR (right). Products from the second round of PCR for c.3470 G>A in COL1A1 from family 1 are shown.

Table 2. Comparison of PCR amplification efficiency and allele dropout using hot start PCR and multiplex nested PCR

\begin{tabular}{|c|c|c|c|c|c|c|c|}
\hline & \multirow{2}{*}{ Mutation } & \multicolumn{3}{|c|}{ PCR amplification efficiency } & \multicolumn{3}{|c|}{ Allele dropout } \\
\hline & & Hot start PCR & Multiplex nested PCR & $P$-value & Hot start PCR & Multiplex nested PCR & $P$-value \\
\hline \multirow[t]{4}{*}{ Family 1} & c.3470 G>A in COL1A1 & $48 / 50(96.0)$ & $49 / 50(98.0)$ & 0.284 & \multirow{4}{*}{$21 / 50(42.0)$} & \multirow{4}{*}{$18 / 50(36.0)$} & \multirow{4}{*}{0.355} \\
\hline & IVS15+5 G>A in COL1A1 & $47 / 50(94.0)$ & $43 / 50(86.0)$ & 0.080 & & & \\
\hline & $Z F X / Z F Y$ & $96 / 100(96.0)$ & $95 / 100(95.0)$ & 0.354 & & & \\
\hline & total & $191 / 200(95.5)$ & $187 / 200(93.5)$ & 0.174 & & & \\
\hline \multirow[t]{3}{*}{ Family 2} & c.3803_3805 dup in COL1A2 & $95 / 100(95.0)$ & $91 / 100(91.0)$ & 0.104 & \multirow{3}{*}{$3 / 50(6.0)$} & \multirow{3}{*}{$7 / 50(14.0)$} & \multirow{3}{*}{$<0.05$} \\
\hline & $Z F X / Z F Y$ & $89 / 100(89.0)$ & 69/100(69.0) & $<0.001$ & & & \\
\hline & total & $184 / 200(92.0)$ & $160 / 200(80.0)$ & $<0.001$ & & & \\
\hline
\end{tabular}

The values are expressed as numbers (\%). dup, duplication 
Table 3. Clinical results from the preimplantation genetic diagnosis for osteogenesis imperfecta in family 2

\begin{tabular}{|c|c|c|c|c|c|c|c|c|}
\hline \multirow{2}{*}{\multicolumn{2}{|c|}{ Cell No. }} & \multirow{2}{*}{ Cell stage } & \multicolumn{3}{|c|}{ Amplification efficiency $(+,-)$} & \multirow{2}{*}{ Sex } & \multirow{2}{*}{ ADO } & \multirow{2}{*}{ Result } \\
\hline & & & COL1A2 & $Z F X / Z F Y$ & Positive control & & & \\
\hline & $1-1$ & $8 \mathrm{C}$ & + & + & - & M & - & A \\
\hline & $1-2$ & & + & + & - & M & - & A \\
\hline \multirow[t]{2}{*}{2} & $2-1$ & $8 \mathrm{C}$ & + & + & - & M & - & A \\
\hline & $2-2$ & & + & + & - & M & - & A \\
\hline \multirow[t]{2}{*}{3} & $3-1$ & $8 \mathrm{C}$ & + & + & - & $\mathrm{F}$ & - & NA \\
\hline & $3-2$ & & + & + & - & $\mathrm{F}$ & - & NA \\
\hline
\end{tabular}

A, affect; ADO, allele dropout; M, Male; F, female; NA, non-affective.

marized in Table 3.

For family 2, five oocytes were collected, three oocytes were suitable for intracytoplasmic sperm injection (ICSI), and three oocytes were fertilized normally. Two blastomeres were biopsied from each embryo on day 3 and were analyzed with positive and negative controls (Table 3 ). In this case, it was not failed amplification and ADO. We selected an unaffected embryo after DNA purification and direct sequencing of the secondary PCR products from the hot start PCR method. Only one unaffected embryo was available for transfer to the uterus on day 5 after the PGD analysis. However, pregnancy was not achieved.

\section{Discussion}

The purpose of this study was to compare the efficacy of the hot start PCR with that of conventional multiplex nested PCR. Our experiments showed that the rate of amplification for hot start PCR is higher than for conventional multiplex nested PCR. And there were fewer nonspecific bands and the PCR band appeared clearly at the correctsize.

The results of ADO in family 1 were $42.0 \%$ and $36.0 \%$ unlike family 2 . The most experienced PGD laboratories are generally able to reduce ADO rates to $5.0-15.0 \%{ }_{1}{ }^{10)}$ but ADO occurred on average in $25.8 \%$ of the samples, ranging between $0.0 \%$ and $60.0 \%{ }^{11,12)}$ ADO may be caused by a combination of inefficient denaturation and degradation of one of the genomic alleles in the first cycles of PCR. ${ }^{13)}$ We were conjectured the result from the long period of storage ( $>12$ month) of lymphocyte in the refrigerator. There was a problem of the donated blood sampling once again.

PCR is an elaborate technique for amplifying small amounts of target DNA, but clinical PGD-PCR cycle requires particular care. PGD for monogenic diseases is susceptible to problems of contamination, PCR failure, and most significantly, ADO, which may lead to misdiagnosis. ${ }^{14,15)}$ We take about three to six months to set up a PCR condition, and it was tested for DNA dilution, single lymphocyte and some blastomeres. It was mostly difficult in that time of diverting from a single level of DNA to a single cell. Therefore, most researchers in a PGD clinic spend much time determining the PCR condition for each PGD cycle.

Taq polymerase is thermostable DNA polymerase that is named after the thermophilic bacterium from which it was originally isolated by Thomas D. Brock in 1965. ${ }^{5)}$ Although the Taq polymerase grows optimally at $70^{\circ} \mathrm{C}$ and cannot grow at moderate temperatures, its DNA polymerase has significant activity at 20 $-37^{\circ} \mathrm{C}$. This activity is a bane to some PCRs, because it catalyzes non-specific priming. ${ }^{16)}$ With hot start amplification, both primer/ template mispriming and the formation of primer dimers, the main sources of undesirable nonspecific DNA amplification, are largely prevented, leading to significantly improved sensitivity and specificity. ${ }^{17,18)}$

Hot start PCR methods can be classified into four large groups: methods that use physical removal of essential reaction components, those that use sequestration of components within the reaction, those that use chemical modification of the polymerase and those that use reversible, ligand-mediated polymerase inhibition. We chose a method that uses the physical removal of essential reaction components. The physical removal method does not require additional materials and reduces the expenses for hot start PCR. Many researchers and companies have improvement to increase the convenience of hot start PCR. For instance, Taq Start antibody provides automatic hot start for increased enzyme specificity and productyield and, cold -sensitive mutations in Klentaq markedly reduce the enzyme's activity at $37^{\circ} \mathrm{C}$ yet allow it to have apparently normal activity at $68^{\circ} \mathrm{C}$ and resistance at $95^{\circ} \mathrm{C}^{19,20}$

Malcov et al. applied the hot start PCR method for PGD for Duchenne muscular dystrophy. ${ }^{211}$ However, this report did not compare conventional multiplexnested PCR with hotstartPCR.Amplificationbased tests can be used for the diagnosis of monogenic defectsat the DNA level of a single cell. ${ }^{22,23}$ Thus, not only methods of DNA amplifi- 
cation and DNA extraction, but also guideline for PGD have been examined. The accurate amplification of a specific region is the most important criterion in the clinical use of PGD. ${ }^{24-26)}$ In conclusion, it is suggested that the hotstartPCR method may bea useful method for PGD-PCR that could improve the success of diagnosis. But this data have obtained only two families. Much more research remains to be done on diverse PGD cases for the method could have the statistical significance.

\section{Acknowledgment}

This study was supported by a grant from the Seoul National University Hospital Research Fund (\#04-2009-0860), Seoul, Korea.

\section{Reference}

1. Handyside AH, Kontogianni EH, Hardy K, Wiston RML. Pregnancies from biopsied human preimplantation embryos sexed by Y-specific DNA amplification. Nature 1990;344:768-70.

2. Harton GL, Magli MC, Lundin K, Montag M, Lemmen J, Harper JC. ESHRE PGD Consortium/Embryology Special Interest Group best practice guidelines for polar body and embryo biopsy for preimplantation genetic diagnosis/screening (PGD/PGS). Hum Reprod 2011;26:41-6.

3. Spits C, Sermon K. PGD for monogenic disorders: aspects of molecular biology. Prenat Diagn 2009;29:50-6.

4. Harper JC, Sengupta SB. Preimplantation genetic diagnosis: State of the ART 2011. Hum Genet 2012;131:175-86.

5. Chien A, Edgar DB, Trela JM. Deoxyribonucleic acid polymerase from the extreme thermophile Thermus aquaticus. J Bacteriol 1976;127: 1550-7.

6. Lebedev A. Heat-activatable primers for hot-start PCR: oligonucleotide synthesis and basic PCR setup. Curr Protoc Nucleic Acid Chem 2009;4. 35:1-17.

7. Kramer MF, Coen DM. Enzymatic amplification of DNA by PCR: standard procedures and optimization. Curr Protoc Immunol 2011; chapter10: unit 10.20 .

8. Malcov M, Schwartz T, Mei-Raz N, Yosef DB, Amit A, Lessing JB, et al. Multiplex nested PCR for preimplantation genetic diagnosis of spinal muscular atrophy. Fetal Diagn Ther 2004;19:199-206.

9. Girardet A, Hamamah S, Déchaud H, Anahory T, Coubes C, Hédon B, et al. Specific detection of deleted and non-deleted dystrophin exons together with gender assignment in preimplantation genetic diagnosis of Duchenne muscular dystrophy. Mol Hum Reprod 2003;9:421-7.

10. Piyamongkol W, Bermúdez MG, Harper JC, Wells D. Detailed investigation of factors influencing amplification efficiency and allele drop-out in single cell PCR: implications for preimplantation genetic diagnosis. Mol Hum Reprod 2003;9:411-20.

11. Handyside $A H$, Robinson MD, Simpson RJ, Omar MB, Shaw MA, Grudzinskas JG, et al. Isothermal whole genome amplification from single and small numbers of cells: a new era for preimplantation genetic diagnosis of inherited disease. Mol Hum Reprod 2004;10:767-72.

12. Ren Z, Zhou C, Xu Y, Deng J, Zeng H, Zeng Y. Mutation and haplotype analysis for Duchenne muscular dystrophy by single cell multiple displacement amplification. Mol Hum Reprod 2007;13:431-6.

13. Ray PF, Handyside AH. Increasing the denaturation temperature during the first cycles of amplification reduces allele dropout from single cells for preimplantation genetic diagnosis. Mol Hum Reprod 1996;2:213-8.

14. Wells D, Sherlock JK. Strategies for preimplantation genetic diagnosis of single gene disorders by DNA amplification. Prenat Diagn 1998;18: 1389-401.

15. Lissens W, Sermon K. Preimplantation genetic diagnosis: current status and new developments. Hum Reprod 1997;12:1756-61.

16. Kermekchiev MB, Tzekov A, Barnes WM. Cold-sensitive mutants of Taq DNA polymerase provide a hot start for PCR. Nucleic Acids Res 2003; 31:6139-47.

17. Chou Q, Russell M, Birch DE, Raymond J, Bloch W. Prevention of prePCR mis-priming and primer dimerization improves low-copy-number amplifications. Nucleic Acids Res 1992;20:1717-23.

18. D'Aquila RT, Bechtel LJ, Videler JA, Eron JJ, Gorczyca P, Kaplan JC. Maximizingsensitivity and specificity of PCR by preamplification heating. Nucleic Acids Res 1991;19:3749.

19. Barnes WM, Rowlyk KR. Magnesium precipitate hot start method for PCR. Mol Cell Probes 2002;16:167-71.

20. Kermekchiev MB, Tzekov A, Barnes WM.Cold-sensitivemutants of Taq DNA polymerase provide a hot start for PCR. Nucleic Acids Res 2003; 31:6139-47.

21. Malcov M, Ben-Yosef D, Schwartz T, Mey-Raz N, AzemF, Lessing JB, et al. Preimplantation genetic diagnosis (PGD) for Duchenne muscular dystrophy (DMD) by triplex-nested PCR. Prenat Diagn 2005;25:1200-5.

22. Sermon KD. Preimplantation genetic diagnosis. Verh K Acad Geneeskd Belg 2006;68:5-32

23. Thornhill AR, Snow K. Molecular diagnostics in preimplantation genetic diagnosis. J Mol Diagn 2002;4:11-29.

24. Kim SA, Yoon JA, Kang MJ, Choi YM, Chae SJ, Moon SY. An efficient and reliable DNA extraction method for preimplantation genetic diagnosis: a comparison of allele drop out and amplification rates using different single cell lysis methods. Fertil Steril 2009;92:814-8.

25. Practice Committee of Society for Assisted Reproductive Technology; Practice Committee of American Society for Reproductive Medicine. Preimplantation genetic testing: a Practice Committee opinion. Fertil Steril 2008;90:136-43.

26. Harton GL, De Rycke M, Fiorentino F, Moutou C, Sen Gupta S, TraegerSynodinos J, et al. ESHREPGD consortium best practice guidelines for amplification-based PGD. Hum Reprod 2011;26:33-40. 